\title{
Sugar content variation in elephant grass germplasm
}

\section{Thalita Bordignon da Cunha $^{1}$ (D) Antonio Vander Pereira ${ }^{1}$ (D) Francisco José da Silva Lédo ${ }^{1}$ (i) Rogério Figueiredo Daher $^{2}$ (D) Juarez Campolina Machado ${ }^{1 *}$}

${ }^{1}$ Embrapa Gado de Leite, Empresa Brasileira de Pesquisa Agropecuária (EMBRAPA), 36038-330, Juiz de Fora, MG, Brasil. E-mail: juarez.machado@embrapa.br. "Corresponding author.

${ }^{2}$ Universidade Estadual do Norte Fluminense Darcy Ribeiro (UENF), Campos do Goytacazes, RJ, Brasil.

ABSTRACT: The objective of this study was to estimate sugar content variation ( ${ }^{\circ}$ Brix) in 95 accessions from the elephant grass germplasm active bank of Embrapa Dairy Cattle research center, located in Coronel Pacheco, MG, Brazil. The accessions with the highest sugar content were identified, and the effect of plant age on sugar concentration was evaluated. The experiment was conducted in randomized blocks design with two replications. Sugar content analysis occurred twice during the growth-cycle (at 70 and 100 days) along two points of the stem, one $30 \mathrm{~cm}$ from the base and the other at the midpoint. The analysis of variance considered the split plot model, with accessions as main plots and plant age as subplots. The means were compared using the Scott Knott test. While there was sugar content variation between accessions, increased plant age had no significant effect on the sugar content. However, some accessions did have a significant increase or decrease in sugar content as they aged. The highest and lowest mean sugar content was $6.96 \%$ (in the accession BAG80) and $4.03 \%$ (in the accession $B A G 13)^{\circ}$ Brix, respectively.

Key words: Pennisetum purpureum, ${ }^{\circ}$ Brix, genetic resources, plant age, forage quality.

Variação do teor de açúcar em germoplasma de capim-elefante

RESUMO: O objetivo deste estudo foi estimar a variação do teor de açúcar ( ${ }^{\circ}$ Brix) existente entre 95 acessos do banco ativo de germoplasma de capim-elefante da Embrapa Gado de Leite, localizado no campo experimental de Coronel Pacheco. Foram identificados os acessos com maior teor de açúcar, bem como avaliado o efeito da idade da planta sobre a variação da concentração de açúcar. O experimento foi conduzido em blocos ao acaso com duas repetições, 95 genótipos, duas idades de planta, 70 e 100 dias de crescimento, e análise do teor de açúcar em duas secções amostradas à $30 \mathrm{~cm}$ da base e na metade do colmo. A análise de variância considerou modelo de parcela subdividida no tempo, sendo os acessos, as parcelas e a idade da planta as subparcelas. As médias foram comparadas pelo teste de Scott Knott. Observou-se variação no teor de açúcar entre os acessos, porém não foi observado efeito significativo no teor de açúcar devido ao aumento da idade da planta. Entretanto, alguns acessos apresentaram interação significativa com aumento ou redução do teor de açúcar em decorrência do aumento da idade da planta. O acesso de maior média de teor de açúcares entre as duas idades foi BAG80, com 6,96\%, e o de menor foi BAG13, com 4,03\%. Palavras-chave: Pennisetum purpureum, ${ }^{\circ}$ Brix, recursos genéticos, idade da planta, qualidade de forragem.

Elephant grass [Pennisetum purpureum Schumach.; synonym Cenchrus purpureus (Schumach.) Morrone] is one of the most important forage species in tropical and subtropical regions owing to its high potential for dry matter production, nutritional value, acceptability, vigor, and persistence. Grown all over Brazil, this crop is an important resource used to supplement pastures during the dry season, where it is provided as green chop or silage (PEREIRA et al., 2017).

Silage is one of the main uses of elephant grass owing to its high yield and low cost compared to other foods. Silage is produced through a forage conservation process in which a mass of tightly- packed vegetation is fermented in an anaerobic, low $\mathrm{pH}$ environment. Under these conditions, anaerobic bacteria consume the soluble carbohydrates within the forage, generating organic acids that decrease the $\mathrm{pH}$. This is important, as the fermentation of silage in a low $\mathrm{pH}$ environment inhibits the multiplication of undesirable microorganisms.

The presence of free sugars in forage plants is essential for the silage fermentation process as well as important for animal nutrition (KUNG et al., 2018). According to GOURLEY \& LUSK (1978), a silage mass needs to contain a minimum of 6 to $8 \%$ soluble carbohydrates in order to provide adequate fermentation and avoid the development

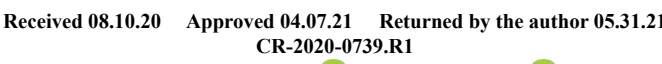


of undesirable secondary fermentations. In forage grasses, soluble carbohydrates are stored mostly in the stem in the form of glucose, fructose, galactose, fructans, and sucrose (WHITE, 1973). However, most forage grasses have low levels of soluble carbohydrates compared to sugar cane, corn, or even other common animal feed.

The Elephant Grass Germplasm Active Bank (BAGCE) of Embrapa Dairy Cattle has 110 accessions of elephant grass, characterized by a set of morphological, agronomic, bromatological, and molecular descriptors (SHIMOYA et al., 2001; AZEVEDO et al., 2012, ROCHA et al., 2017). These characterizations were efficient in describing genetic variability, discriminating accessions, and establishing groups of relative similarity (PEREIRA et al., 2008).

Although elephant grass germplasm contains wide variation among important forage characteristics, the accessions have not been evaluated for variation in soluble carbohydrate content. In addition, no records were found in the literature on the variability of soluble carbohydrate content in Pennisetum germplasm. ROSA \& SILVA (2007) state that the content of soluble carbohydrates decreases with increasing plant age and their composition varies among different cultivars. TSURUTA et al. (2002) reported that sugar content was negatively correlated with morphological characteristics (i.e. tiller, plant length, stem length, stem diameter, node number, internode length and ratio of heading stem). The evaluation of BAGCE accessions will serve to identify genotypic materials with high sugar content that can be used as parents in breeding programs designed to produce cultivars with better silage fermentation patterns. The objective of this study was to quantify the sugar content ( ${ }^{\circ}$ Brix) of elephant grass accessions, identify the accessions with the highest sugar content, and evaluate the effect of increasing plant age on sugar content variation.

The sugar content $\left({ }^{\circ}\right.$ Brix) was evaluated in 95 accessions in the elephant grass germplasm bank, located in the experimental field of Embrapa Dairy Cattle, in Coronel Pacheco, MG, Brazil. The evaluations were conducted during two growth ages, the first at 70 days and the second at 100 days.

Before sampling, the clumps were cut close to the ground to ensure homogeneous growth and to avoid potential effects of different growth ages on the experiment results. Avoiding sugar content variation throughout the day, the study samples were collected and analyzed on the same period in the morning.

Degrees Brix was determined from the mean sugar content of juice extracted from two points along the stem. One point was $30 \mathrm{~cm}$ from the base, while the other was in the middle of the stem. The sampled stems were sectioned and squeezed using pliers to extract the juice. The juice samples from each accession were then placed in a Milwaukee MA871 digital refractometer (accuracy, 85\%) for analysis, where the percentage of sugar was obtained. After every ten grass samplings, the refractometer was tested with distilled water to check its stability and the value set to zero.

The experiment used a randomized block design with two replications, 95 genotypes, and two plant ages (70 and 100 days of growth). The analysis of variance considered the split plot model (RAMALHO et al., 2000), in which the accessions were plots and plant ages were subplots. The means were compared using the Scott Knott test (1974).

The accession (A) effect was significant $(\mathrm{P}<$ $0.01)$; however, plant age (PA) had no significant effect $(\mathrm{P}>0.05)$. The $\mathrm{A} \times \mathrm{PA}$ interaction was significant $(\mathrm{P}<$ 0.01 ), showing that the relative change in sugar content of elephant grass accessions varies by plant age (Table 1). In Panicum maximum, in which two cutting ages were also evaluated, it was observed an effect of age on the levels of soluble carbohydrates, with an increase in its content with the advancing age of the plant (AVILA et al., 2006), however in the present work PA had no significant effect. It infers that 70 and 100 days were not an interval sufficient to differentiate the average sugar content in elephant grass.

The sugar content $\left({ }^{\circ}\right.$ Brix $)$ of elephant grass accessions at the two growth ages are presented in table 2 . It was observed that $35 \%$ of the accessions

Table 1 - Analysis of the variance in sugar content in elephant grass accessions at 70 and 100 days of growth.

\begin{tabular}{|lcc|}
\hline Source of variation & DF & Mean squares \\
\hline Blocks & 1 & 0.203789 \\
\hline Accession (A) & 94 & $1.251495^{* *}$ \\
\hline Error a & 94 & 0.218869 \\
\hline Plant Age (PA) & 1 & $1.579605^{\mathrm{ns}}$ \\
\hline Error b & 1 & 0.017789 \\
\hline Interaction (A x PA) & 94 & $0.588382^{* *}$ \\
\hline Error c & 94 & 0.318587 \\
\hline CV a (\%) & - & 8.14 \\
\hline CV b (\%) & - & 2.32 \\
\hline CV c (\%) & - & 9.82 \\
\hline
\end{tabular}

${ }^{\mathrm{ns}}=$ Not significant. $^{*}$ and ${ }^{* *}=$ Significant at 5 and $1 \%$ probability (F-Test), respectively.

Ciência Rural, v.52, n.1, 2022. 
Table 2 - Sugar content ( ${ }^{\circ}$ Brix) in accessions from the Elephant Grass Germplasm Active Bank evaluated at 70 and 100 days of growth.

\begin{tabular}{|c|c|c|c|c|c|c|c|c|c|c|c|}
\hline \multirow[t]{2}{*}{ BAGCE } & \multicolumn{2}{|c|}{$\begin{array}{l}\text { Plant age (days of } \\
\text {-----growth)----- }\end{array}$} & \multirow[t]{2}{*}{ Mean } & \multirow[t]{2}{*}{ BAGCE } & \multicolumn{2}{|c|}{$\begin{array}{l}\text { Plant age (days of } \\
\text {-------growth)------- }\end{array}$} & \multirow[t]{2}{*}{ Mean } & \multirow[t]{2}{*}{ BAGCE } & \multicolumn{2}{|c|}{$\begin{array}{l}\text { Plant age (days of } \\
\end{array}$} & \multirow[t]{2}{*}{ Mean } \\
\hline & 70 & 100 & & & 70 & 100 & & & 70 & 100 & \\
\hline 1 & $6.43 a$ & $6.13 a$ & $6.28 \mathrm{a}$ & 33 & $5.83 a$ & $5.65 \mathrm{a}$ & $5.74 b$ & 68 & $5.33 b$ & $6.23 \mathrm{a}$ & $5.78 b$ \\
\hline 2 & $5.83 \mathrm{a}$ & $5.53 \mathrm{a}$ & $5.68 b$ & 34 & $6.28 \mathrm{a}$ & $5.65 \mathrm{a}$ & $5.96 \mathrm{~b}$ & 70 & $5.85 \mathrm{a}$ & $5.85 \mathrm{a}$ & $5.85 \mathrm{~b}$ \\
\hline 3 & $6.30 \mathrm{a}$ & $5.88 \mathrm{a}$ & $6.09 \mathrm{~b}$ & 35 & $6.00 \mathrm{a}$ & $5.68 \mathrm{a}$ & $5.84 \mathrm{~b}$ & 71 & $6.30 \mathrm{a}$ & $5.73 \mathrm{a}$ & $6.01 \mathrm{~b}$ \\
\hline 4 & $6.05 \mathrm{a}$ & $6.18 \mathrm{a}$ & $6.11 b$ & 36 & $5.28 \mathrm{~b}$ & $4.08 b^{*}$ & $4.68 \mathrm{~d}$ & 72 & $6.00 \mathrm{a}$ & $6.38 \mathrm{a}$ & $6.19 a$ \\
\hline 5 & $6.10 \mathrm{a}$ & $6.23 \mathrm{a}$ & $6.16 \mathrm{~b}$ & 37 & $6.15 \mathrm{a}$ & $5.58 \mathrm{a}$ & $5.86 \mathrm{~b}$ & 73 & $6.30 \mathrm{a}$ & $6.15 \mathrm{a}$ & $6.23 a$ \\
\hline 6 & $4.70 \mathrm{~b}$ & $5.63 \mathrm{a}$ & $5.16 \mathrm{c}$ & 38 & $5.78 \mathrm{a}$ & $4.95 b$ & $5.36 \mathrm{c}$ & 74 & $5.75 \mathrm{a}$ & $5.18 b$ & $5.46 \mathrm{c}$ \\
\hline 7 & $3.33 \mathrm{c}$ & $5.65 \mathrm{a}^{* *}$ & $4.49 \mathrm{~d}$ & 39 & $4.75 b$ & $4.93 b$ & $4.84 d$ & 75 & $5.70 \mathrm{a}$ & $4.85 b$ & $5.28 \mathrm{c}$ \\
\hline 8 & $6.43 \mathrm{a}$ & $6.35 \mathrm{a}$ & $6.39 \mathrm{a}$ & 40 & $6.18 \mathrm{a}$ & $5.20 \mathrm{~b}$ & $5.69 \mathrm{~b}$ & 76 & $6.43 \mathrm{a}$ & $6.28 \mathrm{a}$ & $6.35 \mathrm{a}$ \\
\hline 9 & $6.13 a$ & $6.05 a$ & $6.09 b$ & 44 & $6.03 \mathrm{a}$ & $5.53 \mathrm{a}$ & $5.78 b$ & 78 & $6.30 \mathrm{a}$ & $5.93 \mathrm{a}$ & $6.11 b$ \\
\hline 10 & $5.23 b$ & $5.88 \mathrm{a}$ & $5.55 \mathrm{c}$ & 45 & $5.53 b$ & $5.65 \mathrm{a}$ & $5.59 \mathrm{c}$ & 79 & $5.20 \mathrm{~b}$ & $5.60 \mathrm{a}$ & $5.40 \mathrm{c}$ \\
\hline 11 & $7.00 \mathrm{a}$ & $5.73 \mathrm{a}^{*}$ & $6.36 \mathrm{a}$ & 46 & $6.73 a$ & $6.00 \mathrm{a}$ & $6.36 \mathrm{a}$ & 80 & $7.48 \mathrm{a}$ & $6.45 a$ & $6.96 a$ \\
\hline 12 & $5.48 b$ & $5.53 \mathrm{a}$ & $5.50 \mathrm{c}$ & 47 & $6.05 a$ & $5.15 \mathrm{~b}$ & $5.60 \mathrm{c}$ & 81 & $5.05 \mathrm{~b}$ & $6.35 \mathrm{a}^{*}$ & $5.70 \mathrm{~b}$ \\
\hline 13 & $2.35 \mathrm{~d}$ & $5.70 \mathrm{a}^{* *}$ & $4.03 \mathrm{~d}$ & 48 & $6.15 \mathrm{a}$ & $5.73 a$ & $5.94 b$ & 82 & $6.00 \mathrm{a}$ & $5.88 \mathrm{a}$ & $5.94 b$ \\
\hline 14 & $4.83 b$ & $5.18 b$ & $5.00 \mathrm{c}$ & 49 & $6.10 \mathrm{a}$ & $5.88 \mathrm{a}$ & $5.99 \mathrm{~b}$ & 83 & $5.98 \mathrm{a}$ & $4.98 b$ & $5.48 \mathrm{c}$ \\
\hline 15 & $6.23 a$ & $6.03 a$ & $6.13 b$ & 50 & $6.60 \mathrm{a}$ & $5.43 b^{*}$ & $6.01 \mathrm{~b}$ & 85 & $5.83 a$ & $5.98 \mathrm{a}$ & $5.90 \mathrm{~b}$ \\
\hline 16 & $5.50 \mathrm{~b}$ & $5.13 \mathrm{~b}$ & $5.31 \mathrm{c}$ & 51 & $5.25 \mathrm{~b}$ & $5.75 a$ & $5.50 \mathrm{c}$ & 86 & $6.53 \mathrm{a}$ & $6.33 \mathrm{a}$ & $6.43 a$ \\
\hline 17 & $5.20 \mathrm{~b}$ & $4.78 \mathrm{~b}$ & $4.99 c$ & 52 & $6.68 \mathrm{a}$ & $5.10 b^{* *}$ & $5.89 \mathrm{~b}$ & 87 & $7.05 \mathrm{a}$ & $5.98 \mathrm{a}$ & $6.51 \mathrm{a}$ \\
\hline 18 & $5.13 b$ & $5.60 \mathrm{a}$ & $5.36 \mathrm{c}$ & 53 & $6.23 \mathrm{a}$ & $5.90 \mathrm{a}$ & $6.06 \mathrm{~b}$ & 88 & $6.00 \mathrm{a}$ & $6.30 \mathrm{a}$ & $6.15 b$ \\
\hline 19 & $6.18 \mathrm{a}$ & $5.98 \mathrm{a}$ & $6.08 b$ & 54 & $6.00 \mathrm{a}$ & $4.93 \mathrm{~b}$ & $5.46 c$ & 91 & $5.43 b$ & $4.75 b$ & $5.09 c$ \\
\hline 20 & $5.65 a$ & $5.55 \mathrm{a}$ & $5.60 \mathrm{c}$ & 55 & $5.98 \mathrm{a}$ & $5.28 \mathrm{~b}$ & $5.63 c$ & 92 & $6.65 \mathrm{a}$ & $6.13 \mathrm{a}$ & $6.39 a$ \\
\hline 21 & $5.15 b$ & $5.55 \mathrm{a}$ & $5.35 \mathrm{c}$ & 56 & $5.90 \mathrm{a}$ & $6.03 a$ & $5.96 \mathrm{~b}$ & 93 & $6.43 a$ & $6.28 \mathrm{a}$ & $6.35 \mathrm{a}$ \\
\hline 22 & $5.80 \mathrm{a}$ & $6.15 \mathrm{a}$ & $5.98 \mathrm{~b}$ & 57 & $6.05 a$ & $5.45 b$ & $5.75 b$ & 94 & $6.40 \mathrm{a}$ & $6.90 \mathrm{a}$ & $6.65 a$ \\
\hline 23 & $4.05 \mathrm{c}$ & $4.40 \mathrm{~b}$ & $4.23 d$ & 58 & $5.43 b$ & $5.38 b$ & $5.40 \mathrm{c}$ & 95 & $7.15 \mathrm{a}$ & $6.60 \mathrm{a}$ & $6.88 \mathrm{a}$ \\
\hline 24 & $5.70 \mathrm{a}$ & $5.33 b$ & $5.51 \mathrm{c}$ & 59 & $5.18 b$ & $6.23 a$ & $5.70 \mathrm{~b}$ & 96 & $6.55 \mathrm{a}$ & $6.03 a$ & $6.29 a$ \\
\hline 25 & $5.75 a$ & $5.83 a$ & $5.79 b$ & 60 & $6.20 \mathrm{a}$ & $5.50 \mathrm{a}$ & $5.85 \mathrm{~b}$ & 97 & $4.88 \mathrm{~b}$ & $6.00 \mathrm{a}^{*}$ & $5.44 c$ \\
\hline 26 & $5.40 \mathrm{~b}$ & $5.75 \mathrm{a}$ & $5.58 \mathrm{c}$ & 61 & $6.10 \mathrm{a}$ & $5.38 b$ & $5.74 b$ & 98 & $4.30 \mathrm{~b}$ & $5.85 \mathrm{a}^{* *}$ & $5.08 \mathrm{c}$ \\
\hline 27 & $6.55 \mathrm{a}$ & $5.93 a$ & $6.24 \mathrm{a}$ & 62 & $7.20 \mathrm{a}$ & $6.35 \mathrm{a}$ & $6.78 \mathrm{a}$ & 99 & $4.85 b$ & $5.08 \mathrm{~b}$ & $4.96 \mathrm{c}$ \\
\hline 28 & $5.68 \mathrm{a}$ & $6.23 \mathrm{a}$ & $5.95 b$ & 63 & $6.63 \mathrm{a}$ & $5.98 \mathrm{a}$ & $6.30 \mathrm{a}$ & 100 & $5.40 \mathrm{~b}$ & $4.63 b$ & $5.01 \mathrm{c}$ \\
\hline 29 & $5.75 a$ & $5.20 \mathrm{~b}$ & $5.48 \mathrm{c}$ & 64 & $6.23 \mathrm{a}$ & $5.98 \mathrm{a}$ & $6.10 \mathrm{~b}$ & 101 & $4.53 b$ & $4.30 \mathrm{~b}$ & $4.41 d$ \\
\hline 30 & $6.70 \mathrm{a}$ & $6.48 \mathrm{a}$ & $6.59 \mathrm{a}$ & 65 & $5.98 \mathrm{a}$ & $4.88 b$ & $5.43 \mathrm{c}$ & 102 & $5.75 \mathrm{a}$ & $5.35 b$ & $5.55 \mathrm{c}$ \\
\hline 31 & $4.50 \mathrm{~b}$ & $6.00 \mathrm{a}^{* *}$ & $5.25 \mathrm{c}$ & 66 & $6.78 \mathrm{a}$ & $5.95 a$ & $6.36 \mathrm{a}$ & Trip. A & $5.53 b$ & $6.53 a$ & $6.03 b$ \\
\hline 32 & $5.80 \mathrm{a}$ & $5.53 \mathrm{a}$ & $5.66 \mathrm{~b}$ & 67 & $5.15 b$ & $4.95 \mathrm{~b}$ & $5.05 \mathrm{c}$ & & & & \\
\hline
\end{tabular}

Means followed by the same letter in the column do not differ according to the Scott Knott cluster test (1974) at 5\% probability. ${ }^{*}$ and ${ }^{* *}$ indicates means differing significantly at $5 \%$ and $1 \%$ probability (F-test), respectively.

had sugar content that was considered adequate in order to provide adequate fermentation and avoid the development of undesirable secondary fermentations (GOURLEY \& LUSK, 1978).

The accessions for each growth age (70 days, 100 days, and the mean growth age) were classified into four groups according to the percentage of sugar found. The Scott Knott test showed that the group with the highest sugar content included 68 accessions from the 70 day growth age and 67 accessions from the 100 day growth age. Based on the mean of these two ages, 20 accessions were highlighted among the highest sugar content group. This group of 20 accessions is of great interest for

Ciência Rural, v.52, n.1, 2022. 
improving elephant grass for silage, direct grazing and the production of energy biomass. These results are consistent with TSURUTA et al., (2002) who evaluated fifteen genotypes for sugar content, including one interspecific hybrid (P. glaucum $x P$. purpureum). The authors cluster together genotypes that showed higher sugar content and lower lignin content than the other types and suggested that these genotypes are useful for the improvement of the forage quality in elephant grass. In addition it has been shown to temperate forages (ryegrass) in direct grazing that increasing the level of soluble carbohydrates have a positive effect on grass intake and milk production (MILLER et al., 1999).

At 70 days of growth, the sugar content of accessions varied from $2.35 \%$ (BAG13) to $7.48 \%$ (BAG80), average in 70 days, while the sugar content at 100 days of growth ranged from $4.08 \%$ (BAG36) to $6.98 \%$ (BAG94) average. Considering the mean for the two growth ages, sugar content was seen to vary from $4.03 \%$ (BAG13) to $6.96 \%$ (BAG80). Taking into account the chemical composition and morpho agronomic traits BAG 80 was classified as presenting good values for: flowering, stalk diameter, dry matter concentration, and nitrogen level, and the accession has been cluster in a group suitable for different uses of the elephant grass (ROCHA et al., 2017).

The analysis of variance results showed significant effects of the $\mathrm{A} \times \mathrm{PA}$ interaction on sugar content. The accessions BAG7, BAG13, BAG31, BAG81, BAG97, and BAG98 increased in sugar content with plant age, while the accessions BAG11, BAG36, BAG50, and BAG52 decreased in sugar content with age. An explanation for this contradictory phenomenon is that as some genotypes age, they transform soluble carbohydrates into insoluble or partially soluble carbohydrates (cellulose and hemicellulose). This consequently increases the cell wall and insoluble fibers. In contrast, other genotypes increase soluble carbohydrate content in the stem as the plant ages (LI et al., 2015). The results of the present work are advancing in relation to those carried out by the authors, however testing the hypothesis may result in important information for animal nutritionists looking to improve elephant grass.

In conclusion, sugar content varied between the elephant grass accessions sourced from the Elephant Grass Germplasm Active Bank and the accessions show differences among themselves in terms of sugar content variation with increasing age.

\section{ACKNOWLEDGEMENTS}

This study was financed in part by the Coordenação de Aperfeiçoamento de Pessoal de Nível Superior -Brasil (CAPES) - Finance Code 001, Conselho Nacional de Desenvolvimento Científico e Tecnológico (CNPq), Fundação de Amparo à Pesquisa do Estado de Minas Gerais (FAPEMIG) and Brazilian Agricultural Research Corporation (Embrapa).

\section{DECLARATION OF CONFLICT OF INTEREST}

We have no conflict of interest to declare. The founding sponsors had no role in the design of the study; in the collection, analyses, or interpretation of data; in the writing of the manuscript, and in the decision to publish the results.

\section{AUTHOR'S CONTRIBUTIONS}

The authors contributed equally to the manuscript.

\section{REFERENCES}

AVILA, C. L. S.; et al.,Water-soluble carbohydrate contents of tanzaniagrass ensiled with additives. Revista Brasileira de Zootecnia, Viçosa, v.35, n.3, p.648-654, 2006. doi: 10.1590/ S1516-35982006000300004

AZEVEDO, A. L. S.; et al., Cross species amplification of microsatellite markers in and genetic diversity of napier grass accessions. Crop Science, v.52, p.1776-1785, 2012. Available from: <https://acsess.onlinelibrary.wiley.com/doi/full/10.2135/ cropsci2011.09.0480>. Accessed: Jul. 16, 2020. doi: 10.2135/ cropsci2011.09.0480.

GOURLEY, L. M.; LUSK, J. W. Genetic parameters related to sorghum silage quality. Journal of Dairy Science, v.61, n.12, p.1821-1827, 1978. Available from: <https://www.sciencedirect. com/science/article/pii/S0022030278838089>. Accessed: Jul. 16, 2020. doi: 10.3168/jds.S0022-0302(78)83808-9.

KUNG Jr., L.; et al., Silage review: Interpretation of chemical, microbial, and organoleptic components of silages. Journal of Dairy Science, v.101, p.4020-4033, 2018. Available from: $<$ https:// www.sciencedirect.com/science/article/pii/S0022030218303242>. Accessed: Jul. 16, 2020. doi: 10.3168/jds.2017-13909.

LI, Y.; et al., Preliminary evaluation of five elephant grass cultivars harvested at different time for sugar production. Chinese Journal of Chemical Engineering, v.23, p.1188-1193, 2015. Available from <https://www.sciencedirect.com/science/article/abs/pii/ S1004954115001482>. Accessed: Jul. 16, 2020. doi: 10.1016/j. cjche.2015.04.016.

MILLER, L. A.; et al., Milk production and N partitioning in dairy cows offered perennial ryegrass selected for high watersoluble carbohydrate concentrations. South African Journal of Animal Science. v.29, p.281-282, 1999.

PEREIRA, A. V.; et al., Diversidade genética entre acessos de capim-elefante obtida com marcadores moleculares. Revista Brasileira de Zootecnia, v.37, p.1216-1221, 2008. Available from: 
$<$ http://www.scielo.br/scielo.php?script=sci_arttext\&pid=S151635982008000700011\&lng=en\&nrm=iso $>$. Accessed: Aug. 07, 2020. doi: $10.1590 / \mathrm{S} 1516-35982008000700011$.

PEREIRA,A. V.; et al., BRS Kurumi and BRS Capiaçu - New elephant grass cultivars for grazing and cut-and-carry system. Crop Breeding and Applied Biotechnology, Viçosa, v.17, n.1, p.59-62, Mar. 2017. Available from: $\quad<\mathrm{http} / /$ www.scielo.br/scielo.php?script $=$ sci arttext\&pid $=$ S 1984-70332017000100059\&lng $=$ en\&nrm=iso $>$. Accessed: Jul. 16, 2020. doi: 10.1590/1984-70332017v17n1c9.

RAMALHO, M. A. P.; et al., Experimentação em genética e melhoramento de plantas. Lavras: UFLA, 2000. 326p.

ROCHA, J. R. A. S. C.; et al., Bioenergetic potential and genetic diversity of elephantgrass via morpho-agronomic and biomass quality traits. Industrial Crops and Products, v.95, p.485-492, 2017, doi: 10.1016/j.indcrop.2016.10.060.

ROSA, B.; SILVA, S. R. C. Produção e características químicas do capim-elefante (Pennisetum purpureum Schum) para ensilagem em diferentes idades de corte. Pesquisa Agropecuária Tropical (Agricultural Research in the Tropics), v.27, n.2, p.99-107,
2007. Available from: <https://www.revistas.ufg.br/pat/article/ view/2974>. Accessed: Jul. 16, 2020.

SCOTT, A. J.; KNOTT, M. A cluster analysis method for grouping means in the analyses of variance. Biometrics, Washington, v.30, p.507-512, 1974. Available from: <https://www.jstor.org/stable/ pdf/2529204.pdf?seq=1>. Accessed: Jul. 16, 2020

SHIMOYA, A.; et al., Comportamento morfo-agronômico de genótipos de capim-elefante. Revista Ceres, Viçosa, v.48, n.276, p.1-19, 2001. Available from: <https://www.locus.ufv.br/bitstream/ handle/123456789/20890/artigo.pdf? sequence $=1 \&$ isAllowed $=y>$. Accessed: Jul. 16, 2020.

TSURUTA, S.; R. et al., Phylogenic variation of morphological characteristics and their relationship with brix and lignin content in Napier grass (Pennisetum purpureum Schumach). Grassland Science, v.47, p.604-609, 2002.

WHITE, L. M. Carbohydrate reserves of grasses: a review. Journal of Range Management, p.13-18, 1973. Available from: <https:// journals.uair.arizona.edu/index.php/jrm/article/view/6131/0>. Accessed: Jul. 16, 2020. 